\title{
10 health stories that mattered this week: Jan. 19-23
}

- Two human rights groups sued the federal government over the use of solitary confinement in prisons. The BC Civil Liberties Association and the John Howard Society of Canada filed the suit in the BC Supreme Court arguing that solitary confinement is unconstitutional, leads to prisoner deaths, and discriminates against Aboriginal inmates and those with mental illness.

- Health Canada added two new rare and serious adverse effects to the prescribing information for the Alzheimer drug donepezil. The department warned that the prescription medicine has been linked to rhabdomyolysis, a condition involving muscle breakdown, and neuroleptic malignant syndrome, which affects the nervous, muscular and cardiovascular systems.

- Canadian doctors decried a recent move by the federal government to quietly undermine the legal basis for a contested refugee health care program while the issue was still before the courts. The Canadian Doctors for Refugee Care will return to Federal Court on Jan. 27 in an effort to force Ottawa to comply with a July 2014 ruling that reversed cuts to health care for refugee claimants.

- Ontario's chief coroner will investigate the death of 11-year-old Makayla Sault, the New Credit First Nation girl who died Jan. 19 after her family decided to stop chemotherapy for acute lymphoblastic leu- kemia in favour of traditional and naturopathic treatments. Sault's family claims that she died of a stroke caused by the 12 weeks of chemotherapy she underwent in early 2014 - a claim rejected by oncologists, according to the Toronto Star.

- A new medical centre that will provide abortion services is set to open in the former Morgentaler Clinic in Fredericton, New Brunswick. Clinic 554, which will be the province's only private abortion clinic, came about as the result of a fundraising campaign organized by reproductive rights advocates after the Morgentaler Clinic closed in July 2014.

- Arbitrator James Dorsey ruled that Nova Scotia can slash the number of bargaining units for health workers from 50 to 4 . Under the new Health Authorities Act, there will be four separate unions for nurses, health care workers, clerical workers and support staff - a move that existing unions say contravenes the charter by denying freedom of association.

- Health care aides working in longterm care facilities and nursing homes in the prairie provinces are poorly understood, have few standards for minimum education and receive widely different training, according to a survey published in the Canadian Journal on Aging. Over half of the participants were born outside Canada and did not speak English as a first language. Aides also reported moderately high levels of burnout.

- Seventeen Alberta health groups called for a new tax on sugary drinks to generate revenue and lower rates of obesity, hypertension, heart disease and diabetes. The Alberta Policy Coalition for Chronic Disease Prevention estimates that a levy of 50 cents per litre could net the province some $\$ 158$ million annually, even if sales dropped $20 \%$ after the tax is implemented.

- British Columbia health officials revealed that some 10000 patients underwent procedures with improperly cleaned endoscopes between 2012 and December 2015 at the University Hospital of Northern BC in Prince George. The BC Centre for Disease Control says the risk of transmitting a viral infection is extremely low.

- Ontario froze compensation for physicians after contract negotiations collapsed. The Ontario Medical Association rejected the government's final offer of a three-year deal that would have seen the total spending on physicians increase by $1.25 \%$ each year to $\$ 11.72$ billion in 2016-2017. Now, the province says compensation will not increase beyond a "modest" bump to add 700 new doctors to the workforce. Lauren Vogel, CMAJ

CMAJ 2015. DOI:10.1503/cmaj.109-4983 